\title{
Mitigating Post Development Flood Using Best Management Practices: A Study of Detention Pond
}

\author{
Khan Mujiburrehman* \\ Environmental Engineer, Dar al Handasah, Makkah, Saudi Arabia
}

"Corresponding Author: Khan Mujiburrehman, Environmental Engineer, Dar al Handasah, Makkah, Saudi Arabia

\begin{abstract}
The main objective of this study is to analyze and calculate the hydrological benefit of providing onsite detention pond for sub catchment Mahiminside Mithi River watershed. The Mithi River watershed is one of the most developed regions in India with the rapid urbanization which serves as an excellent case study site for proving the benefit of detention pond. SWMM 5.1 software has been used to simulate the model and to evaluate the result. The detention pond was found very effective to reduce the peak of flood and to postpone its time of occurrence. The size of detention pond with varying configuration of weirs/orifice plays vital role in flood management. The result obtained shows that (1) the onsite detention of rainwater can reduce the peak flood and can increase its time to occurrences; (2) peak flow is approximately reduced by $52 \%$ and its time of occurrence increase by 180 minutes, respectively; (3) analysis of results shows that successive events of rainfall can exaggerate the flood. In conclusion, detention pond with other best management practices will be very useful. The study suggested that more attention must be given for flood mitigation and water resources management in planning future urban development in the region.
\end{abstract}

Keywords: Detention Pond, Mithi River, Pre and Post Development, SWMM 5.1, Urbanization.

\section{INTRODUCTION}

India has been undergoing rapid urbanization since independence. While the total population of India at the time of independence in 1947 was about 270 million, the urban population is now 285 million out of which about 108 million live in 35 metropolitan cities alone, and the total population is now 1,027 million. A metropolitan city is defined as an urban area having a population of more than a million [1]. The urban population is projected to increase to 618 million by 2021 spread over ten mega cities and 60 metros. In almost all cities of India development in the water supply have out spaced the capacity of storm water drainage. With increase in water supply to urban metros, the drainage managers are faced with the task of managing the additional waste water from the highly populated areas for which the existing drains are inadequate. In addition, over $75 \%$ of the total rainfall occurs mainly in the monsoon season during the four months from June to September. A major challenge is to manage the huge volume of monsoon runoff during these four months. There have been increasing instances of severe flooding followed by epidemics not only disrupting the daily life during monsoons, but also affecting the overall quality of life in most of the metros. Mumbai receives almost all of its2,300 mm rainfall during June to September and several catchments in Mumbai experiences severe flooding usually when high tide is preceded by heavy rainfall for four hours. This period of heavy rainfall causes severe disruption to the transportation system and paralyses commercial activities at least twice a year and the losses are estimated at 5 million USD per flood event [2].With increasing urbanization and the pressures of population, the impervious area in the urban area is increasing.

The natural holding basins detention ponds have been leveled and new housing estates have come on to these sites. Intensive redevelopments and urban consolidations cause increase in surface storm water runoff due to the increased hard surface like roofs and pavements etc. This excess runoff in most of the cases cannot be accommodated by existing drainage system and thus there is a flooding in downstream area. This may also result in flooding of private property. One of the solutions to this is provision of detention system and inline weir which provides temporary storage of storm water runoff from catchments and releases runoff from the detention pond at a controlled rate for which existing 
drainage system is capable of accommodating. Detention system consists of small watershed storage facility having weir to drain the surplus runoff. The weir has openings, size of which depends upon the desired outflow. The outflow can be controlled by gated orifice. It reduces the peak runoff at a downstream of catchment by controlling outflow with the help of weir. The positive aspect of detention pond is that it has the ability to mitigate flood, which would inundate the existing drainage system, located to upstream of the catchment. Thus Detention ponds are flood control structures, which can be used to reduce the peak runoff and can save the low lying downstream area from flooding.

\section{FLOOD AND ITS HAZARDS IN MUMBai CITY}

Mumbai city having an area of $437 \mathrm{sq} \mathrm{km}$ with a population of 12 million came to a complete halt due to the unprecedented rainfall of $944 \mathrm{~mm}$ during the 24 hours starting on 26th July 2005; with $380 \mathrm{~mm}$ falling in just 3 hours between 14:30 to 17:30 and hourly rainfall exceeding $190 \mathrm{~mm} / \mathrm{hr}$ [2]. The immediate impact of the heavy rainfall was that there was a total collapse of the transport and communication system. Both the main Mumbai Santacruz airport and Juhu airport had to be closed down for two days on 26-27 July, 2005, thus forcing over 705 flights either to be diverted or cancelled. Most arterial roads and highways in the suburbs were severely affected due to water logging and traffic jams resulting from breakdown of vehicles in deep waters. Intercity train services had to be cancelled for over a week; while suburban trains could 3 not operate from 16:30 (26th July, 2005) onwards for the next 36 hours. Many people spent the night in offices, schools, trains and some even on the top of the buses. The phone networks also collapsed and people were totally cutoff from each other. Electricity too was cut off in most part of Mumbai. This heavy rainfall resulted in failure of sewage pumps and further led to backflow of sewage into the storm water. Excessive rainfall resulted in water logging several areas of the suburb with water entering even the first floor flats in areas. At least 419 people lost their lives including 65 killed inland slides. Also, 216 car cases were disposed off. A substantial number of buildings were damaged, 2000 residential buildings fully damaged while 50,000 were partially damaged and 40,000 commercial establishments suffered heavy losses. 30,000 vehicles were damaged and 850 buses of Mumbai transport (B.E.S.T) were damaged. Some vehicle occupants lost their lives because they could not open their power windows as their car engines went dead after being submerged in flood waters. The economic losses are considerable and have adverse secondary effects on the economy of the country [2].

Most part of the Mumbai city areas have been developed through filling, and effective drainage is not possible, especially during high tide conditions. Furthermore, Mumbai city is affected by the tidal variations, making the problem more complex. In Mumbai city region, the tide is seen reaching levels of more than $2.5 \mathrm{~m}$ above mean sea level (MSL). If heavy rainfall also occurs simultaneously, then severe flooding will take place. To deal with the urban flooding problem, it is necessary to consider the negative impacts of urbanization on the hydrology of a watershed. Atypical abatement plan is to use the best management practices like constructing a detention pond at the outlet of the catchment to provide storage that can reduce the peak flow and flooding at low lying downstream area.

\section{EFFECTS OF RAPID URBANIZATION}

Urbanization typically results in increased impervious surfaces that reduce the infiltration rate; new drainage channels that increases velocity, and decreases travel time of flood waters; and reservoirs that, in general, reduce and delay flood peaks [3]. Urbanization in flood plain area increases the risk of flooding due to increased peak runoff and volume, and decreased time to peak [4]. Runoff from a portion of the drainage area that is highly impervious may result in a greater peak runoff that would occur if the entire area was considered [5]. The expansion of impervious surfaces decreases aquifer recharge, increases overall hydraulic efficiency by reducing travel times, leads to more frequent flooding due to increased peak discharges and total runoff volume, increases pollutant loading and erosion, and increases channel instability [4]. Urban watersheds, on an average, lose $90 \%$ of the storm rainfall to runoff, whereas the non-urban forested watersheds retain $25 \%$ of the rainfall [6]. A survey by the US (United States of America) Department of Agriculture found that urbanization was implicated in wetland loss in nearly all surveyed watersheds (96\%) and may account for as much as $58 \%$ of the total wetland loss [7]. Land use change in a basin leads to modification of hydrological processes over a range of temporal and spatial scales. It can affect the runoff generation and flow patterns by altering hydrological factors such as interception, infiltration and evaporation, and thus causes changes in the frequency and intensity of flooding. At a catchment scale, such impacts on 
hydrological processes will significantly influence the ecosystem, environment and local economy. Therefore, a better understanding and assessment of land use change impacts on watershed hydrologic process is of great importance for predicting flood potential and the mitigation of flood hazards, and has become a crucial issue for planning, management, and sustainable development of the watershed [8]. Land use change is a major force altering the hydrological processes over a range of temporal and spatial scales. On a catchment scale, such impacts on the hydrological processes, in turn, will significantly influence the ecosystem, environment and economy. Therefore, a better understanding and assessment of land use change impacts on the watershed hydrologic processes, is of great importance for the prediction and mitigation of flood hazards, and also for the planning, sustainable development and management of the watershed [8]. The long-term impacts of increased imperviousness leads to decreased stream water quality, reduced stream habitat, increased habitat fragmentation, lower fish populations, and loss of biodiversity [4]. Overall the effects of urbanization are faster, stronger, bigger floods, which have greater erosive power and do more damage. It is almost as if the natural environment responds to urban growth by increasing its ability to return the environment to its natural state.

\section{Flooding DUE To RAPID URBANiZATION}

Flooding is defined as a temporary inundation of all or part of the floodplain or temporary localized inundation occurring when surface water runoff moves via surface flow, gutters and sewers. Floods also occur when water levels of lakes, ponds, reservoirs, aquifers and estuaries exceed some critical values and inundate the adjacent land [9]. Floods are natural events that have always been an integral part of the geologic history of earth. The impact off loading was not felt to the same extent in the past as its now. This could be due to the rapid increase in population and consequent increase in the human activities [10]. Flooding in urban areas is a major problem. In the year 2005, many urban flooding events have been recorded across the world at various places like Mumbai (India), Wuzhou (China), New Orleans (USA), Quetzaltenango (Guatemala), Bern (Switzerland) etc. Many Indian cities like Mumbai (July 26, 2005), Hyderabad (October 25, 2005), Bangalore (October 24, 2005), Vadodara (June29, 2005), Chennai (December 03, 2005) have also witnessed urban flooding in 2005 [11]. Flooding in coastal urban areas because of heavy rainfall and high tide is now becoming a major concern, especially with the predicted climate change, impacts of sea level rise and high intensity of rainfall. The annual disasters from urban floods are now much greater than the annual economic losses caused by other disasters. For example, major cities in India have witnessed losses of life and property, disruption to transport and power, and incidences of epidemic during monsoons, most notable among them is Mumbai in 2005, Surat in 2006, and Kolkata in 2007 [12].The effects of impervious cover have been extensively examined as a major element of altered hydrologic response in urban river basins [13]. [14] Explained how directly connected impervious area can affect runoff volume. Studies and analysis have shown that damage flooding induced by storm events is a major concern in many regions of the world. Urbanization has profound impacts on the storm event hydrologic response of river basins. The impact of man-made changes on the hydrology of developing watersheds can be measured in terms of the ratio i.e. flood peak after development to flood peak before development over arrange of return periods [15]. Due to encroachment of the flood plain areas, the presence of several structures on river, and the absence of proper regulations for maintenance, an artificial flood are created [16].The design, construction and operation of many hydraulic projects require an adequate knowledge of the variation of the catchment's runoff, and for most of these problems it would be ideal to know the exact magnitude and the actual time of occurrence of all stream flow events during the construction period and economic life of the project. If this information is available at the project planning and design stage, it would be possible to select from amongst all alternatives with an optimized objective function [17].

\section{DETENTION POND}

A detention pond mitigates adverse impacts of excess water by holding that water and releasing it at a rate that will not cause flood on downstream. This is illustrated by the example hydrograph shown in Figure 1. In this Figure, the target outflow (release from detention pond)is $90 \mathrm{~m}^{3} / \mathrm{sec}$. The inflow peak is $100 \mathrm{~m}^{3} / \mathrm{sec}$. To reduce this peak to the target level, storage is provided. Thus the volume of water represented by the hatched area is stored and then released gradually. The total volume of the inflow hydrograph and the volume of the outflow hydrograph (the dotted line) are the same, but the time distribution of the runoff is altered by the storage facility. Storm-water management is one of the 
major tasks for preserving an urban water environment [18]. A storm-water drainage system consists of conveyance and storage facilities. Detention and retention basins are the major storage facilities designed for storm water quantity and quality controls [19]. Storm water management in urban areas is becoming increasingly oriented to the use of low impact development (LID), sustainable urban drainage systems (SUDS), water sensitive urban design (WSUD), best management practices (BMP), or low impact urban design and development (LIUDD) for countering the effects of urban growth, wherein the storm water is controlled at its source through detention, retention, infiltration, storage, and retardation [20]. The application of source control options in storm water management will improve the ecological integrity of rivers and streams, reduces flooding in the city and in downstream areas, reduces sediment transport, and mitigates erosion; consequently, urban storm water can become a true resource instead of a nuisance [21].

Detention basins are a common feature of storm water management programs in urban areas and vast literature is available for design of detention basins [22]. Detention ponds serve to collect water from developed areas and release it by detention facilities at a slower rate than it enters, with the excess of inflow over outflow temporarily stored in a pond. In principle, adequate performance of detention pond might change the level of or even eliminate the impervious-area threshold that produces recognizable aquatic system degradation. There are number of methods available to reduce the peak storm water runoff. These methods include structural measures, such as wetlands, ponds, swales; soak ways, infiltration trenches, roof storage systems, detention/retention basins, infiltration basins, bio retention devices, vegetated filter strips, filter strips, and pervious pavements. The primary objective of these measures is to replicate the pre-urbanization run-off hydrograph. Under appropriate conditions, these structural measures have proven to be effective [23]. An on-stream detention approach is to drain a channel into a widened floodplain area, whereas an off-stream detention approach is to divert storm water from the channel into an adjacent basin. The standard for assessing the performance of detention pond should be first defined so as to evaluate whether the design facility has served its purpose. Storage facilities in a drainage network should be placed at strategic locations to effectively attenuate peak flood flows [22].

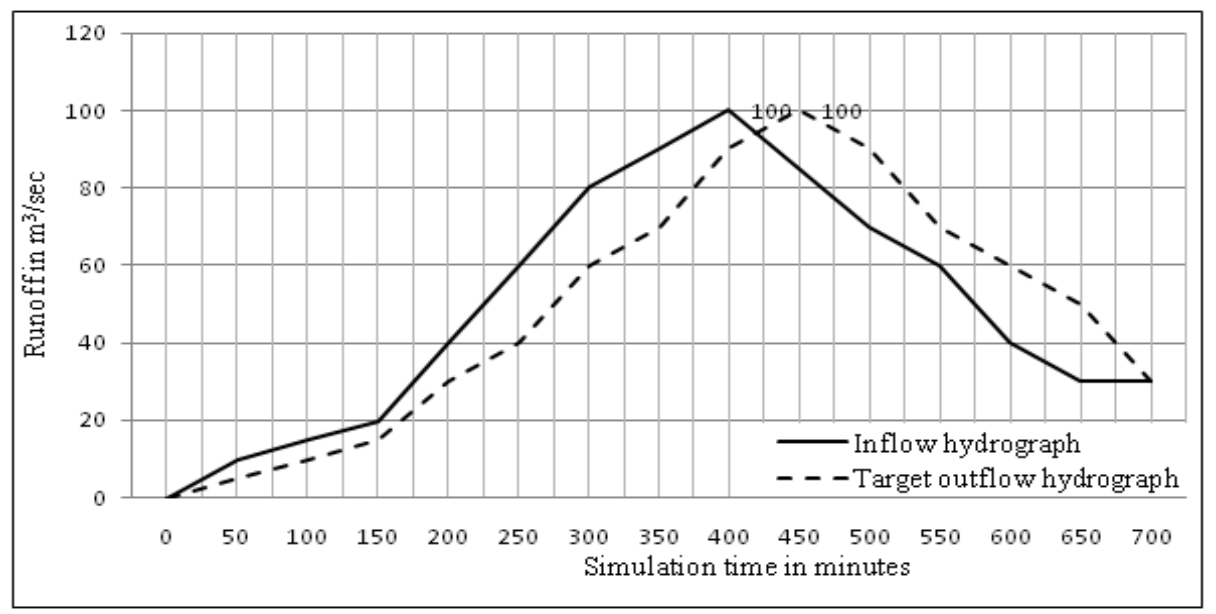

\section{Methods of Sizing The Detention Pond}

Akan (1990) proposed a desktop method to size detention pond and the outlet facility for a multiple return period used the usual reservoirs technique and coupled with the hydrologic storage equation then equation is rearranged in terms of several dimensionless parameters. Results were obtained by employing computer model to solve the governing equation using numerical method and presented in chart form these result can be used directly for computing of initial parameters. [24] Defined the reduction of peak flow by an "efficiency function", which identified the peak reduction ratio and the relative storage ratio of unregulated detention reservoirs. Efficiency function depends not only on the physical features of the reservoir and its outlet, but also on the shape of the inflow hydrograph. Moreover, there have been many suggestions made on the design or operation of detention pond for improving the detention efficiency.

[25]Approximates the relationship for the sizing of detention reservoirs with uncontrolled outlets and these relationships express in terms of the required flood storage as a fraction of the flood volume, and the peak outflow, as a fraction of the peak inflow. Assumptions involved for routing of floods that 
water surface is essentially horizontal and the outflow is unaffected by tail water, another outflow can be expressed as a function of storage because both outflow and storage are functions of water-surface elevation. The water-surface relationship between water-surface area and stage is represented by the function and expressed in term of storage-stage, also outflow and storage are both functions of stage, outflow can be expressed directly as a function of storage and now these relationships can be expressed as the dimensionless form of the equations, submerged outlet is more efficient than an overflow outlet in that considerably less storage is needed to achieve the same peak outflow.[26] developed the routing equations for detention systems from an approximate analytical solution of the nonlinear storage differential equation; solution is obtained by a two term perturbation expansion in which, first-order approximation, allows arbitrary multi event inflow hydrographs, irregular reservoir configuration, and various types and sizes of outlets. Governing storage equation is a nonlinear first order ordinary differential equation, where a solution requires the use of finite differences or the Runge - Kutta method. Results are generalized in a graphical form that relates the peak outflow attenuation and the maximum storage with the inflow and reservoir characteristics. The shape of the inflow hydrograph does not affect the peak values significantly. Triangular inflow hydrograph was used to derive general design equations for detention reservoirs and outlet configurations.

[27] proposed an off-line detention pond so that only a portion of the runoff is directed to the basin; the results demonstrated that off-line systems require considerably less storage than in-line systems to achieve the same management goal.[28] used the mathematical model to evaluate alternative storm water detention policies for Montgomery country. The input data such as precipitation and flow into and from the detention basin was used and calibrated. They realized that many existing storm water management policies do not meet their intent because they ignore the volume duration frequency concept that has been used in hydrologic design. They conclude that less costly design are possible if both basin volume and outlet characteristics are considered simultaneously.

[29] analyzed how the hydraulic performance differs between 13 ponds with hypothetically different layouts; he indicated that an island placed in front of the inlet improves the hydraulic performance, and that a curved pond or an island placed near the side does not deteriorate the performance.[30] gave the idea of design storm approach describe statistical characteristics of rainfall conditions for use in flood plain and flood control analysis and design, for these, storms of various durations are developed through statistical analysis of the rainfall history of a location. Numerical hydrologic models are used to transform the input design storms into corresponding output runoff hydrographs from the catchment. Pond performance under possible future rainfall conditions is evaluated through numeric modeling of the systems with input design storms of various return periods. Continuous simulation uses historical rainfall data directly as input to a continuous simulation of hydrologic model of the catchment and associated control structures analytical probabilistic approach an alternative to the above two approaches for characterization $\mathrm{f}$ rainfall conditions and for evaluation of their impacts on the performance of urban flood control detention ponds, and it has based on different way of statistically analyzing historical rainfall records a continuous rainfall series is first divided into discrete rainfall events.[31] presented a hydrology-based approach that requires only the inflow hydrograph and the maximum allowable release rate to assess the detention storage volume and also to perform the reservoir routing through the proposed detention basin. The performance of a basin is examined by a reservoir routing procedure, here continuity principle is rearranged to provide two new routing functions, one solution by storage volume, and the other in terms of flow rate. Storageoutflow curve has developed and described in terms of overflow, cumulative storage and will be used for the preliminary storage-outflow curve for the basin under design.[32] investigated the different combination of inflow and outflow for calculation of detention storage volume and also calculated the peak flow rate delay. It may induce the worst damage to the downstream. The unit hydrograph can be calculated by combining IDF (intensity duration frequency) curve with the rational method. To calculate the detention storage volume, two types of hydrographs based on rainfall durations in which possible combinations of inflow hydrograph with outflow hydrograph are made and for each combination the storage volume in detention pond is calculated. Also for the calculated delay time of peak flow a comparison is made for each combination. By observation, triangular inflow and outflow hydrograph combination has the maximum storage volume whereas trapezoidal inflow and triangular outflow combination has the minimum storage also for the triangular inflow the ratio of peak flow time to end flow time and time to peak is proportional to delay of peak flow, while for the trapezoidal inflow the ratio of the duration time of rainfall and time to peak is proportional to delay of peak flow. 
[32] Gave the idea of detention basin design by the estimation of its volume, solved the problem of hydrological continuity equation by a numerical model and graphical method according to the detention pond routing phenomena. Model uses the fourth-order Runge-Kutta method to solve the continuity equation with triangular inflow hydrograph, adds base flow to the equation of detention pond type feature for more general application. The resulting charts are useful for determining necessary parameters for detention pond design with different triangular inflow hydrographs, detention pond configurations and outflow devices.

\section{Materials ANd Method}

\subsection{Study Area}

The area studied in this paper is sub catchment of Mithi River watershed (Mahim) which is located between north latitudes of $19^{\circ} 1{ }^{\prime} 36^{\prime \prime}$ and $19^{\circ} 10^{\prime} 9^{\prime \prime}$ and east longitudes of $72^{\circ} 49^{\prime} 59^{\prime \prime}$ and $72^{\circ} 566^{\prime} 33^{\prime \prime}$. The location of the Mithi River has been shown in Figure 1 .

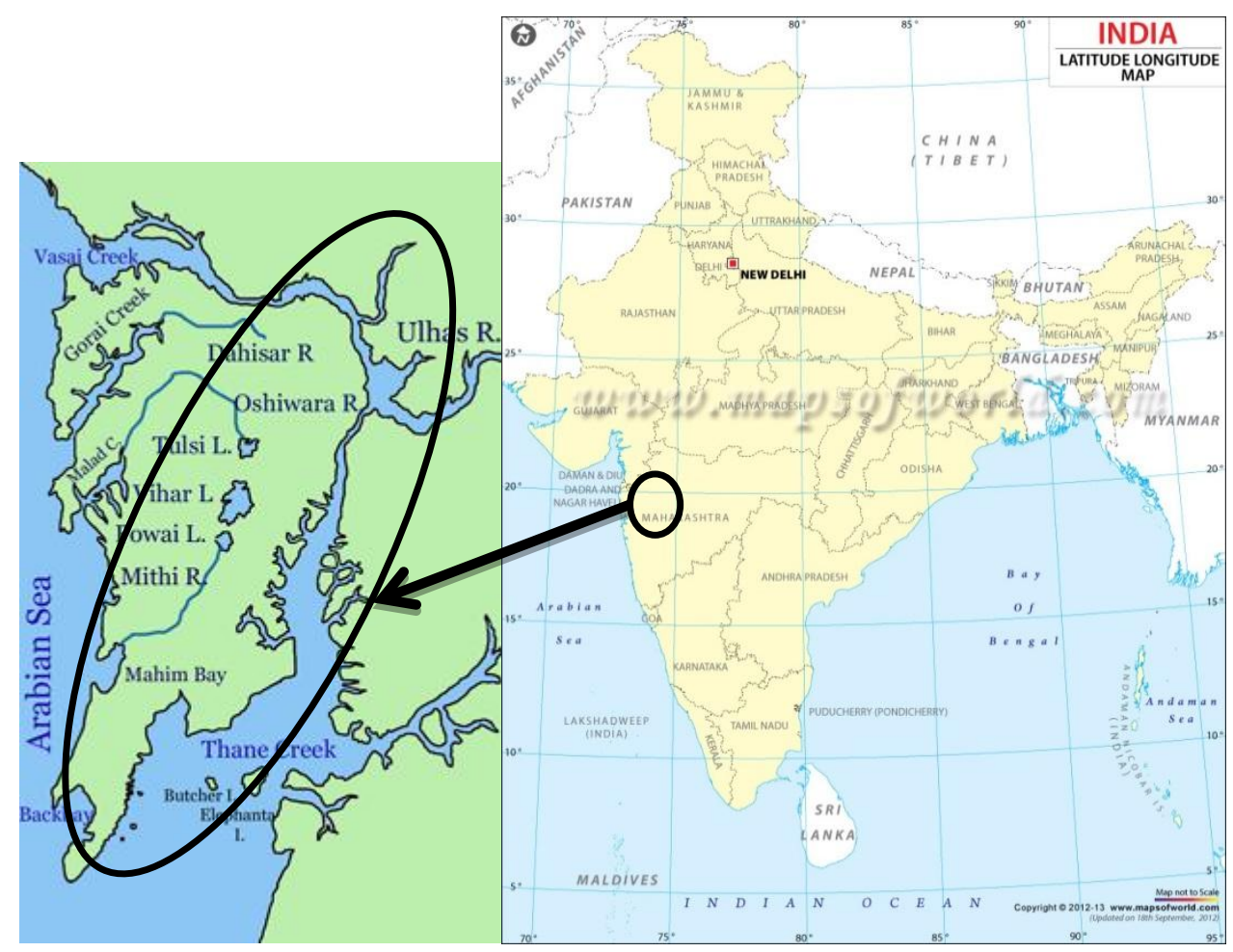

Figure1. Location of Mithi River (source: India Lat \& Lon Map. (2012))

The Mithi River basin, one of the main rivers of Mumbai which plays crucial part in draining most of the rain water into Arabia Sea. The maximum annual rainfall in Mumbai ever recorded was 3,452 mm (136 inch) for 1954 (Mumbai plan, 2009). The highest rainfall recorded in a single day was $944 \mathrm{~mm}$ (37 in) on 26th July 2005. The average total annual rainfall is $2,146.6 \mathrm{~mm}$ ( $85 \mathrm{in}$ ) for the Island City, and 2,457 mm (97 in) for the suburbs (Mumbai plan, 2009). Nearly $90 \%$ of area has been developed for residential, commercial, industrial and institutional use while $10 \%$ is covered by green cover and mangroves (Mujib K., 2012). Rapid urbanization and industrial growth have increased pressure on the flow capacities of the Mithi River and its tributaries.

\subsection{Soil Classification of Study Area}

According to the soil classification, the sub catchment is mainly occupied by soils of the type C, which are characterized by low intensity of infiltration and, therefore, a risk of runoff above average and a high risk of erosion. Considering this classification, taking into account the type of land use, curve number $\mathrm{CN}$ was estimated for the watershed.

\subsection{Land Use of Study Area}

In recent decades, the watershed of Mithi River has suffered an intense growth of urban areas, which has contributed to the increase in impervious area and, consequently, to increased risk of flooding. Presently, about $90 \%$ of the watershed area is occupied by urban centers, being that urbanization is 
more intense in the downstream of Mithi River. The Sub catchment Mahim and its hydrological model in SWMM 5.1 have been shown in Figure 2. The sub catchment Mahim has been considered as full impervious because of high intensity development in that area.

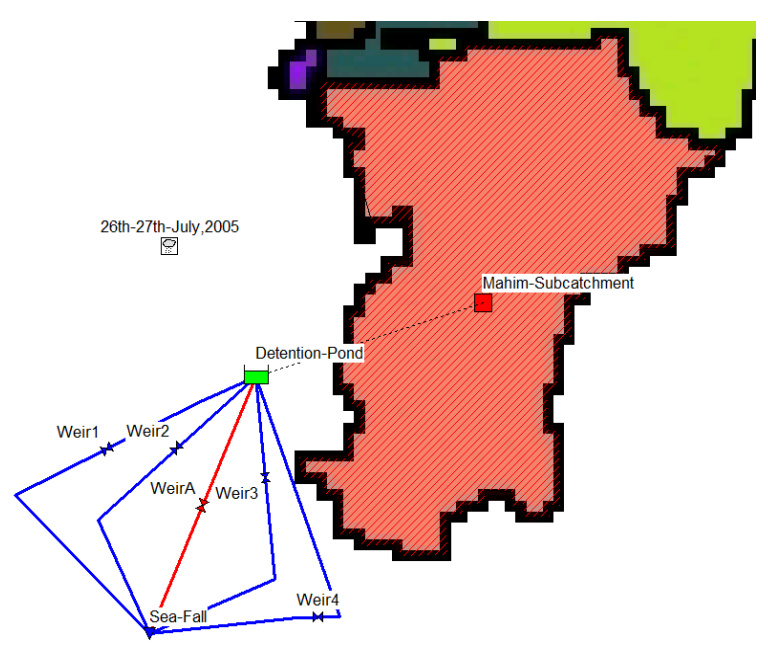

Figure2. Sub catchment Mahim and Hydrological model in SWMM 5.1

\subsection{SimulatingMitigating Effect of Detention Pond Using SWMM5.1}

To simulate the mitigating effect of detention pond using SWMM 5.1, we used the SWMM 5.1 (Storm Water Management Model). The sub catchment Mahim is plotted in SWMM 5.1 and required input data was entered. The area of sub catchment Mahim is 644ha with average basin slope $7.7 \%$. The average width of basin in the direction perpendicular to flow is 2666 linear meter. The $100 \%$ imperviousness was considered.

The 26th July, 2005 rainfall as shown in Figure 3 was used to simulate the model. Two scenarios were considered. One without the detention pond and other considering the effect of detention pond on peak flow and its time of occurrence.

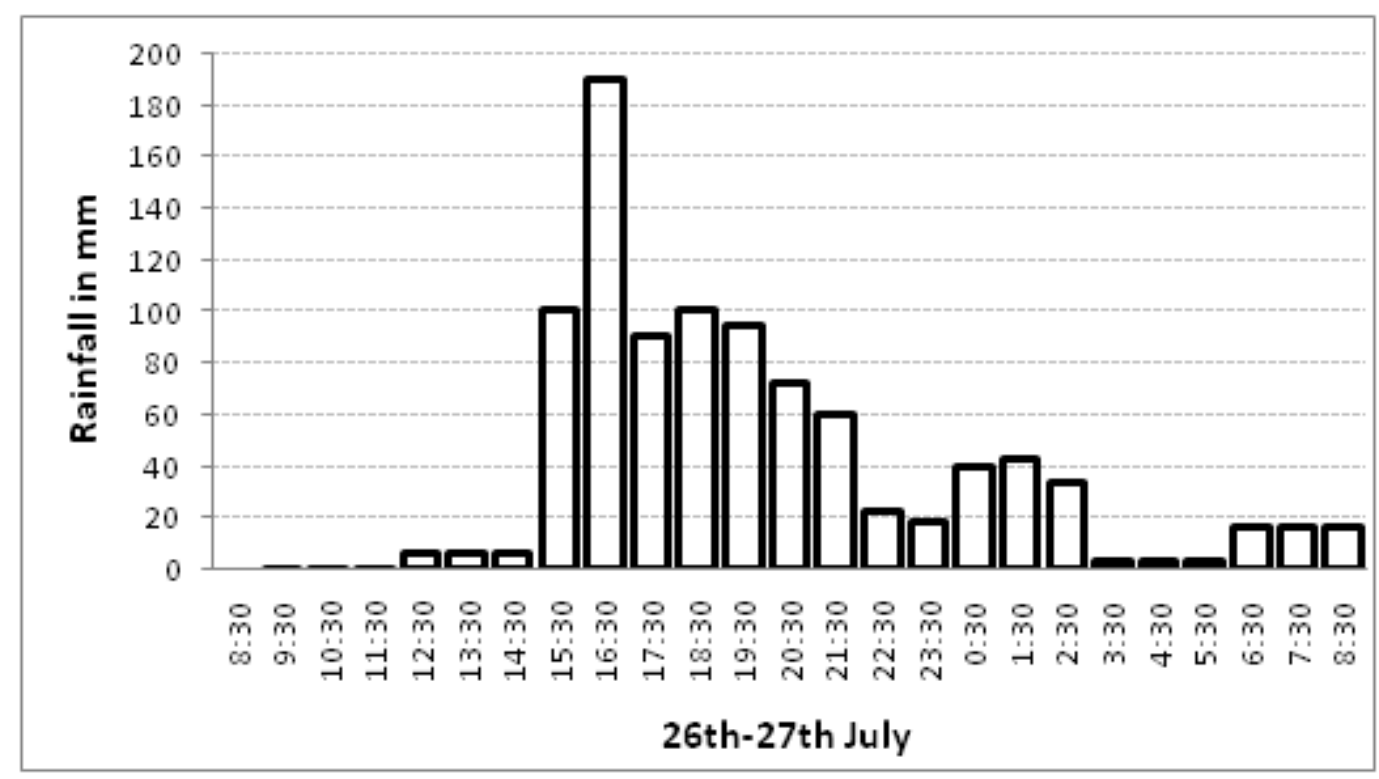

Figure3. 26th - 27th July, 2005 Rainfall in Mumbai, India

\section{RESUlTS AND DisCuSSIONS}

\subsection{Simulation of Sub Catchment Mahim without Considering Effect of Detention Pond}

The Mithi river sub catchment has been simulated using SWMM 5.1. The results have been shown in Figure 4. The simulation shows that peak flow is 340.40 cumecs and occurring at 9:30 PM. The multiple peaks in flood hydrograph are due to complex geometry of sub catchment and varying intensity of rainfall. With such a magnitude of flow (flood) and occurring in very short time is very difficult to control. Such high magnitude of flow is due to rapid urbanization which is converting 
everything into impervious surface. In such circumstances, detention pond can be a vital structure to prevent flooding.

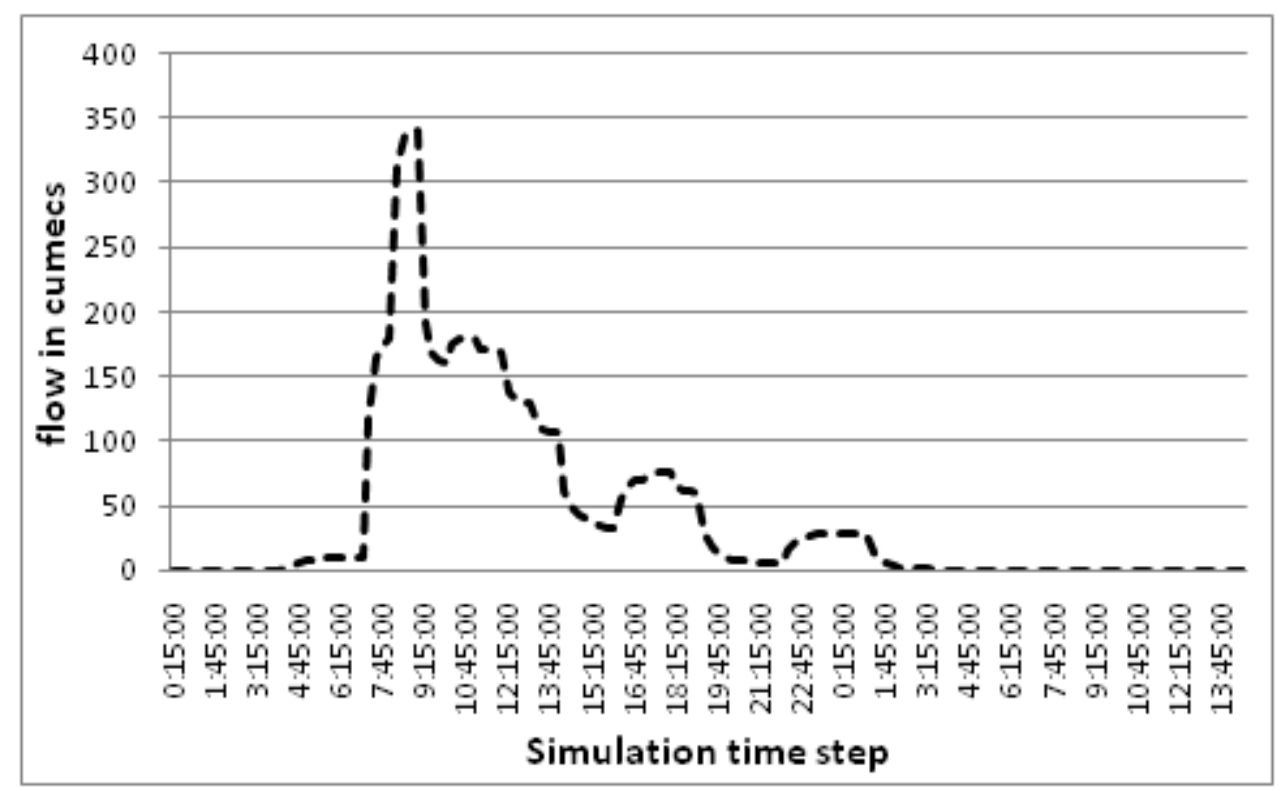

Figure4. Discharge from Mahim sub catchment at Sea Fall

\subsection{Simulation of Sub Catchment Mahim Considering Effect of Detention Pond:}

The detention pond was incorporated into the model at downstream side of sub catchment Mahim. It was decided that peak flow will be reduced to 50\% approximately of post developed flow (340.4 cumecs). For such a big size of sub catchment without any onsite flood control (rain water harvesting, pervious parking etc), it is obvious that size of detention pond required will be very large and impractical. The volume of detention pond considered is $5 \mathrm{~km}^{2}(1000000 * 5)$ to control the historical flood of $26^{\text {th }}$ July. The size and configuration of detention pond has been shown in Figure 5. The maximum depth of pond was taken as $5 \mathrm{~m}$. The combinations of weir were used to release the water from detention pond safely and in timely manner.

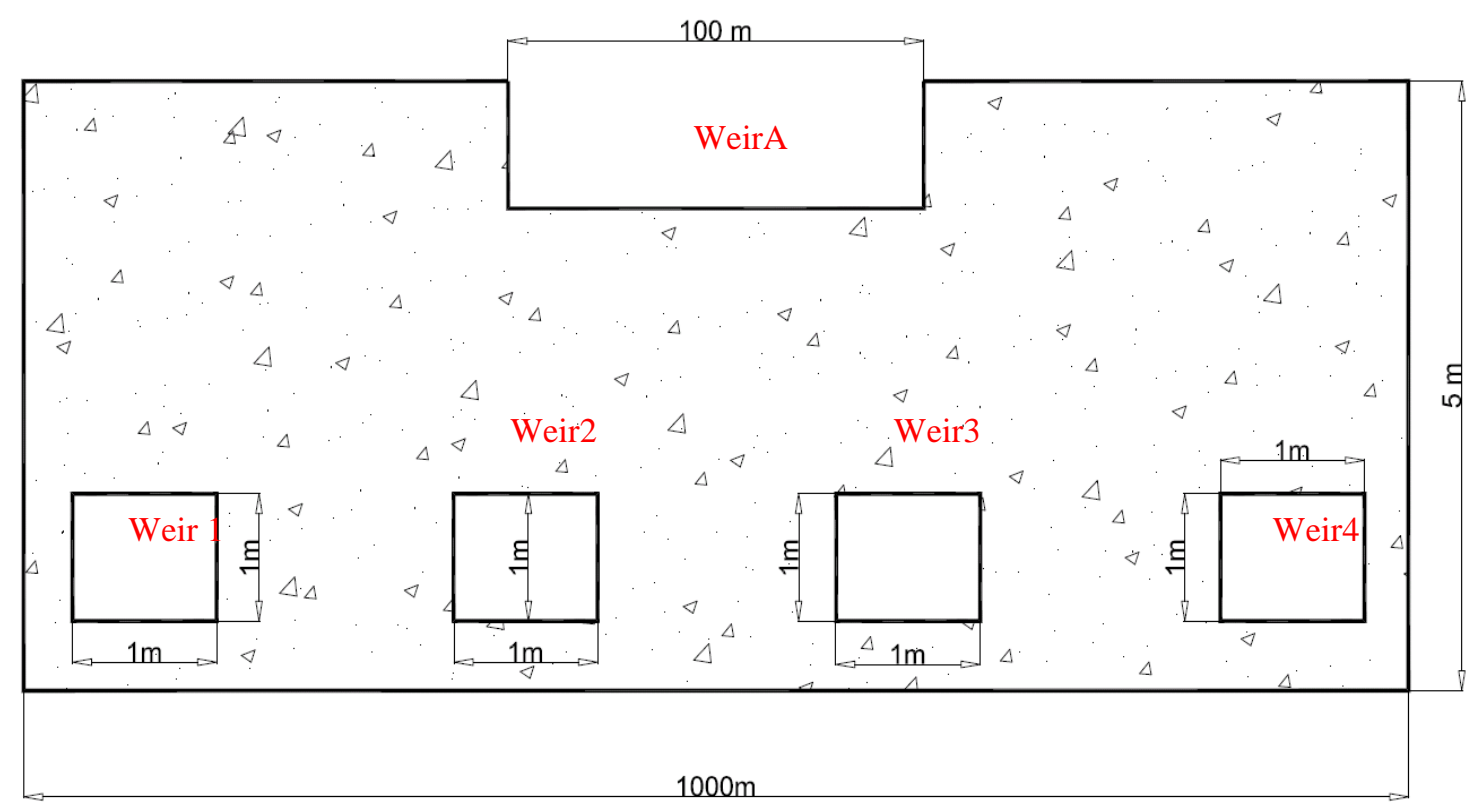

Figure5.Front elevation of detention pond

The detention pond is successful in reducing the peak flow and delaying its time of occurrence. The simulation (see Figure 6) shows that peak flow is reduced from 340.40 cumec to 163.82 cumec (52\% reduction). Also the time to peak is increased by three hours which will give relief to Mithi River. In beginning the detention pond will store the water up to the bottom level of weir and then it will start releasing the water to downstream side of detention pond. 


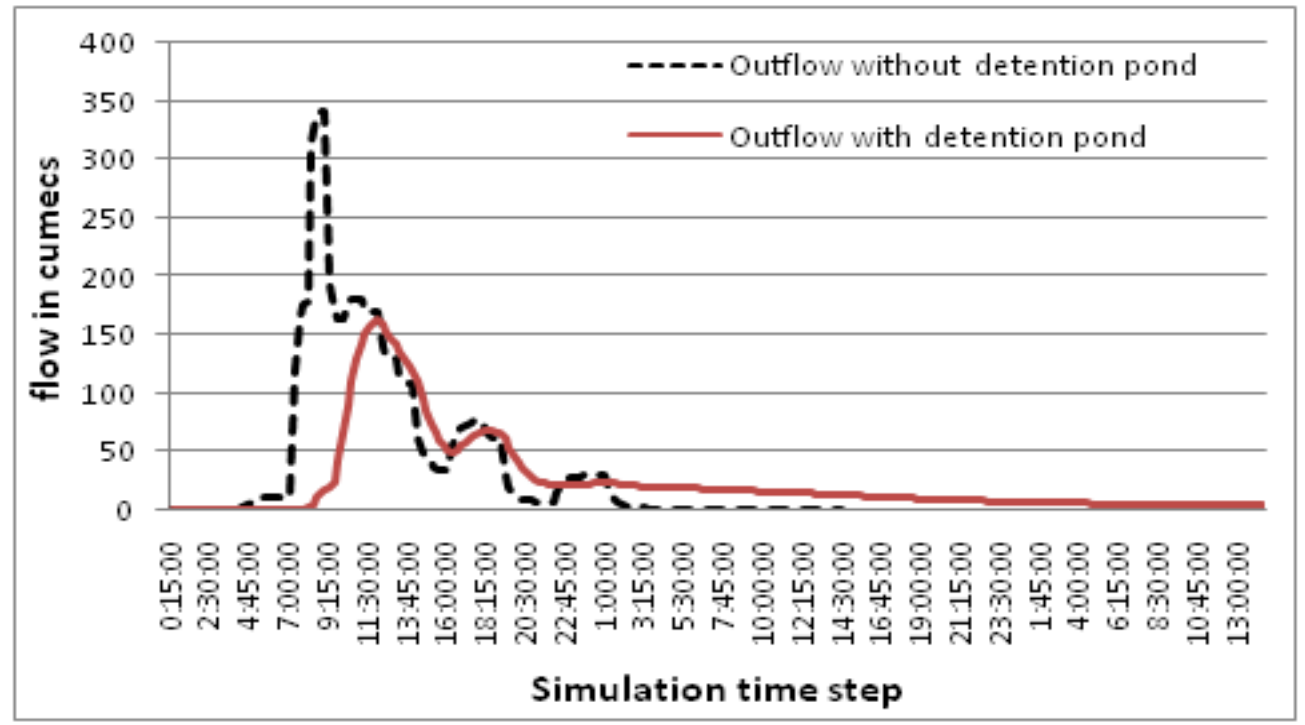

Figure5. Flood attenuation using onsite detention pond

During simulation it was made sure that detention pond never overflows. Hence flooding was always maintained zero (see Figure) by providing four transverse rectangular weir of size $(1 \mathrm{~m} * 1 \mathrm{~m})$ and one large weir on top of size $(100 \mathrm{~m} * 1 \mathrm{~m})$. The maximum depth of water in detention pond reaches to $2.51 \mathrm{~m}$ as shown in Figure at peak flow which is safe.Figure 6, and 7 shows the volume, depth and flooding in detention pond respectively. The civil authority may also utilize the detention pond water for the domestic or commercial use. However standing water in the pond may pose serious health challenge due to mosquito breeding. Best management plan is must for operating detention pond.

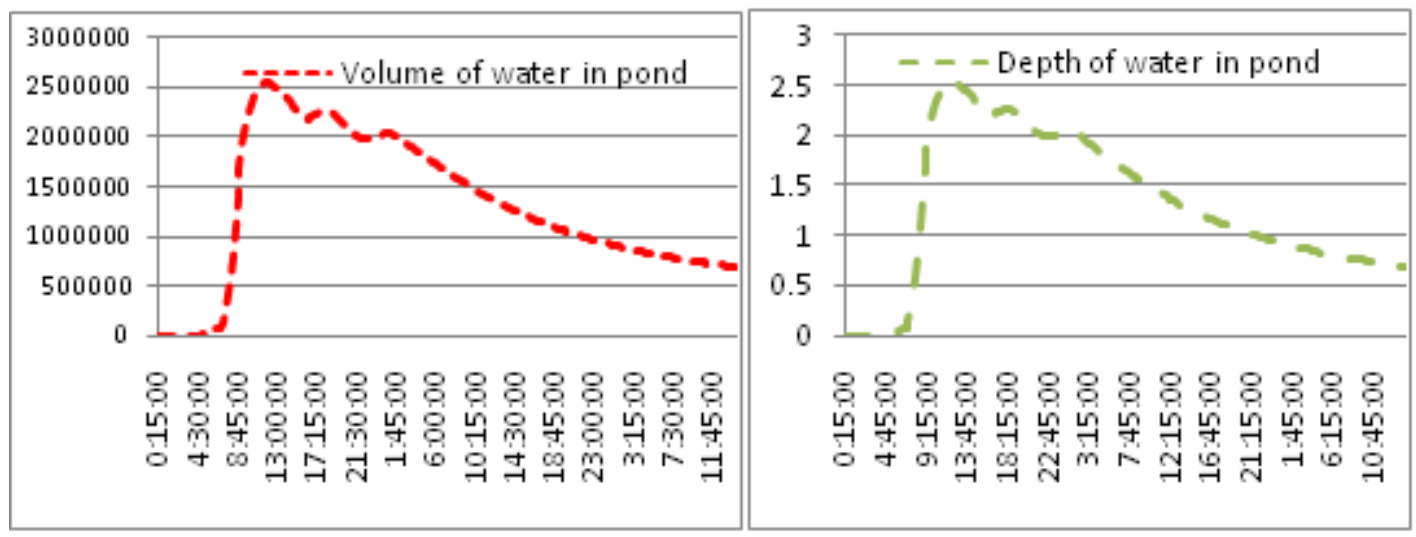

Figure6.Volume $\left(\mathrm{m}^{3}\right)$ and depth of water in detention pond

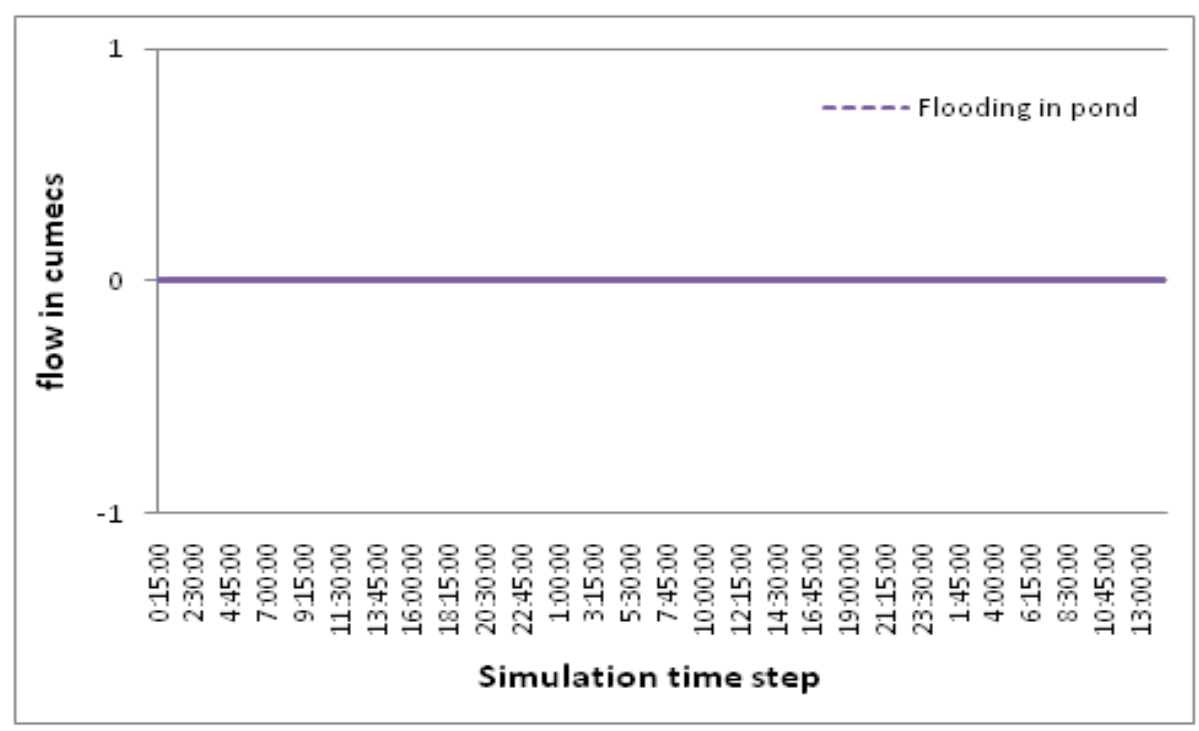

Figure7.Flooding in detention pond 


\section{CONCLusions}

Urbanization generally increases the size and frequency of floods and may expose communities to increasing flood hazards. Current study provides a scientific foundation for flood planning and management in urban areas. The current study emphasizes the benefits of providing detention pond in reducing the peak flood and also increasing its time of occurrence, giving maximum time to people and emergency services to react. The peak flood can be easily reduced to $50 \%$ by providing detention pond at critical locations. However best management practices always bring risk with it. During successive storm, which generally occurs in coastal city like Mumbai, the detention pond may be ineffective or may exaggerate the effect of flood. The civil authority should have plan for all such situations. The size of detention pond can be easily reduced by educating the people about onsite storage of water such as rain water harvesting. Hence provision of detention pond with combination of other best management practices can be very effective methodology to prevent the city from flood hazards.

\section{REFERENCES}

[1] Census of India (2001). "Urban agglomerations/cities having population of more than onemillion in 2001". Office of the Registrar General, India, Government of India, New Delhi,India, available at http:/www.censusindia.net/results/million_plus.html

[2] Gupta, K. (2006). "Waste water disposal in the major cities of India". International Journal ofEnvironment and Pollution, Vol. 28, Nos. 1/2, 2006.

[3] Singh, V. P., and Woolhiser, D.A. (2002). "Mathematical modeling of watershed hydrology."Journal of Hydrologic Engineering, 7, 270-292.

[4] Schuler, T. R. (1994). "The importance of imperviousness.” Watershed Protection Tech., 1_3_,100-110.

[5] Debo T. N., Reese, A. J. (1995). "Municipal storm water management". Lewis Publishers, BocaRaton, Florida, USA.

[6] Shang, J., Wilson, J.P., (2009). "Watershed urbanization and changing flood behavior across theLos Angeles metropolitan region”. Natural Hazards 48, 41-57.

[7] Anon. (1997). "Agricultural resources and environmental indicators". US. Dept. of Agric., Washington, DC.

[8] Chen, Y., Xu, Y., and Yin, Y. (2009). "Impacts of land use change scenarios on storm runoffgeneration in Xitiaoxi basin, China”. Quaternary International, 1-8.

[9] Linmei, N. (2003). "Flooding analysis of urban drainage systems". A dissertation submitted forDoctorate in Engineering, The Faculty of Engineering Science and Technology, theNorwegian University of Science and Technology, Norway.

[10] Todini, E. (1999). "An operational decision support system for flood risk mapping, forecastingand management". Urban Water, 1: 131-143.

[11] Kamini, J., Satish, C., Raghavswamy, V. (2006), "Spatio-temporal analysis of land use in urbanMumbai using multi-sensor satellite data and GIS techniques", Journal of the IndianSociety of Remote Sensing, Vol. 34, No. 4.

[12] Shahapur, S. S., Eldho, T. I., Rao, E. P. (2011) "Flood Simulation in an urban catchment of NaviMumbai city with detention pond and tidal effects using FEM, GIS, and Remote sensing”.Journal of Waterway, Port, Coastal, Ocean. 137, 286 (2011).

[13] Leopold, L. (1968). "Hydrology for urban land Planning - A Guide book on the hydrologic effects of urban land Use". Geological Survey Circular 554, U.S. Geological Survey, Reston, Virginia.

[14] Lee, J. G. and Heaney, J. P. (2003). "Estimation of urban imperviousness and its Impacts on storm water systems". J. Water Res. Plan. Man., Sep. /Oct., vol. 129:5,419-426.

[15] Kibler, D.F., Froelich, C.D., and Aron, G. "Analyzing urbanization impacts on Pennsylvaniaflood peaks". Journal of American Water Resources Association, 17 (2) (2007), pp. 270-274.

[16] Mohapatra, P.K., Singh, R.D. (2003). "Flood management in India". Natural Hazards 28, 131-143.

[17] Blanchard B. R. D., Berry K. A. and Showalter P. S. (2001). "Should flood insurance bemandatory? Insights in the wake of the 1997 New Year's Day flood in Reno-SparksNevada”. Applied Geography, 21:199-221.

[18] ASCE (1994). "Design and construction of urban storm water management system," AmericanSociety of Civil Engineers, Manuals Reports of Engineering Practice No 77, Chapter 1.

[19] Guo, Y., and Adams, B. J. (1999). "An analytical probabilistic approach to sizing flood controldetention facilities”. Water Resour. Res., 35(8), 2457-2468. 
[20] Elliott, A. H., and Trowsdale, S. A. (2007). "A review of models for low impact urban stormwater drainage". Environ. Model Software, 22(3), 394-405.

[21] Braden, J.B. and D.M. Johnston. (2004). "Downstream economic benefits from stormwaterManagement." Journal of Water Resources Planning and Management 130 (6):498-505.

[22] Jones, J., Guo, J.C.Y., and Urbonas, B. (2006). "Safety on detention and retention pond designs",J. of Storm Water, Jan/Feb.

[23] Goonetilleke A., Thomas E., Ginn S., and Gilbert D. (2005), "Understanding the role of landuse in urban storm water quality management", Journal of Environmental Management 74(2005) 31-42.

[24] Kessler, A. and Diskin, M. H. (1991) "The efficiency functions of detention reservoirs in urbandrainage systems". Water Resources Research, Vol. 27, No. 3, pp. 253-258.

[25] McEnore, B.M. (1992). Preliminary sizing of detention reservoirs to reduce peak discharges. J.Hydraul. Eng. 118 (11), 1540e1549 (ASCE).

[26] Basha, (1994). "Nonlinear reservoir routing: particular analytical solution". Journal ofHydrologic Engineering ASCE 120 (5) (1994), pp. 624-632.

[27] Nix, S. J. and Durrans, S. R. (1996). “Off-line storm water detention systems”. Water ResourcesBulletin, Vol. 32, No. 6, pp. 1329-1340.

[28] Kamedulski, G.E. and McCuen, R.H. (1979). "Evaluation of alternative storm water detentionpolicies". Journal of Water Resources Planning and Management Division, 105,pp. 1146-1152.

[29] Persson, J. (2000), “The hydraulic performance of ponds of various layouts”. J. Urban Water 2/3, pp. 243250.

[30] Guo, Y. (2002). "Hydrologic design of urban flood control detention ponds" Journal ofHydrologic Engg., ASCE 6 (6), 472-479.

[31] Guo, J. C. Y. (2004). "Hydrology-based approach to storm water detention basin design usingnew routing schemes". J. Hydrologic. Engg. 9 (4), 333e336.

[32] Hong, Y.M., Yeh, N., and Chen, J.Y. (2006). "The simplified methods on evaluating detentionstorage volume for small catchment". Ecol. Eng. 26 (4), 355e364.

[33] Mujib K.,2012. Evaluation of flood control structures on Mithi River, Mumbai, India, and thesis submitted for Master of technology, IIT Bombay.

\section{AUTHORS' BIOGRAPHY}

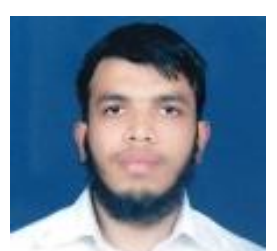

Professor Mujiburrehman khan received his bachelor's degree in Civil engineering from M.H. Saboo Siddik College of Engineering, Mumbai in India in 2009 and his Master degree in Water resources engineering from Indian Institute of Technology, Bombay in 2012. He started a career in teaching at St John College of Engineering and Technology as a lecturer. He has taught various subject such as Engineering geology, Building construction, Building design and drawing, Steel structures, fluid mechanics, Structural analysis (determinate and indeterminate) and Water resources engineering. Professor Mujiburrehman khan joined Dar al Handasah consultant in 2012 as an Environmental engineer in Pune, India. Professor Khan's research areas include the storm water management, Flood management using various GIS techniques. Till date, he has 15 national/international journal published papers in his name. He is accredited with LEED AP BD+C credential from USGBC.

Citation: Khan Mujiburrehman. "Mitigation Post Development Flood Using Best Management Practices: A Study of Detention Pond”. International Journal of Research in Geography. vol 4, no. 4, 2018, pp. 1-11.doi: http://dx.doi.org/10.20431/2454-8685.0404001.

Copyright: (C) 2018 Authors. This is an open-access article distributed under the terms of the Creative Commons Attribution License, which permits unrestricted use, distribution, and reproduction in any medium, provided the original author and source are credited. 